\title{
Identification of signals mediated the treatment of cancer by curcumin extract.
}

\author{
Jehan A. Khan* \\ Department of Biology (Genomic Division), Faculty of Science, King Abdulaziz University, Jeddah, Kingdom of Saudi \\ Arabia
}

\begin{abstract}
Background: The plant polyphenols play a vital role in human diets that link to health and resilience evolutionarily and mechanistically.

Materials and methods: The rational of this study to identify the signals mediated the treatment of cancer by curcumin extract.

Results: Different cancer cell line will be used for detection of the signal molecules of apoptotic during treatment with Methanol Extract of Curcumin (MEC). Hep2G and HeLa cell lines were used treated with 10, 20 and $40 \mu \mathrm{l}$ of MEC. Analysis of MEC by GC/MS referred presence of 1, 3, 5-benzenetriol as active ingredients. In vitro study, the anticancer activity of 1, 3, 5-benzenetriol were $87 \%$ and $85 \%$ for HeLA and HepG2 respectively.

Conclusion: Curcumin as an efficient medicinal displayed a significant effect on HeLa and HepG2 cells which is very effective in the treatment of cancer this is due to presence of $1,3,5$-benzenetriol.
\end{abstract}

Keywords: Curcumin extract, Anticancer, Signal transduction.

Accepted on October 26, 2017

\section{Introduction}

Plant polyphenols are a structurally and functionally diverse family of secondary natural products shaped by adaptive evolution as chemical responses to biotic and abiotic factors impinging on the sessile life style of plants [1]. The role of plant natural products in plant survival, the co-evolution of animals and plants the role of animals in plant reproduction and dispersal, and the presence of plant polyphenols in human diets link plant and human health and resilience evolutionarily and mechanistically [2]. Polyphenol biosynthesis provides a plethora of compounds that collectively reduce chronic inflammation in humans. Polyphenols in plant fruits comprise flavanones, flavones, flavanols, flavan-3, 4-diols, catechins, proanthocyanidins, anthocyanidins and stilbenes [3]. Additionally, these core chemical structures are extensively amended by biosynthetic tailoring reactions encompassing regioselective oxidative couplings, methylations, acylation, glycosylation and prenylation [4]. These latter alterations often impart distinct bioactivity-bioavailability properties on the core polyphenolic scaffolds and contribute to synergistic multicomponent interactions in more complex mixtures [5].

Curcumin extracted from the rhizomes of a perennial herb Curcuma longa with wide leaves has gained immense interest in the scientific community due to its anti-bacterial anti-fungal anti-viral, anti-cancer, anti-inflammatory, anti-malarial, antioxidant and wound healing properties. Asian countries like India and China have used turmeric as a traditional medicine for nearly 2000 years in the form of a paste or an oral form to treat various ailments of skin and illnesses successfully until the modern medicine found it prominent in the last two centuries curcumin was isolated in crystalline form [6].

Signal transduction is essential for all living cell function [7] development [8], differentiation [9], apotosis and cell death. Signaling molecules including hormones, neurotransmitters, and growth factors [10]. Signals mediated by a growth factor involve binding to its receptor initiates a process that starts with the binding with membrane or intracellular receptor [11]. The amplified signal is then propagated to the nucleus, resulting in induction or repression of gene expression [12]. Mitochondrial dysfunction was suggested to be related with many chronic diseases. The rational of this study to identify the signals mediated the treatment of cancer by curcumin extract. Oxidative damage is often related with path physiology of many diseases [13].

Understanding the active anticancer ingredients of curcumin is important biological processes as gene expression, protein synthesis, development, carcinogenesis and apoptosis.

\section{Materials and Methods}

\section{Identification of MEC by GC/MS}

Methanol Optima LC/MS grade from Fisher (NJ, USA) and hexane $95 \%$ for organic residue analysis from Avantor (PA, 
USA) were used for sample preparation GC/MS 5975 (Agilent, CA, USA) system including Agilent 7890 A gas chromatography.

\section{Assessment of antitumor activity of cell culture and treatment}

HeLa and HepG2 and non-cancerous BHK (Baby hamster kidney) cells were obtained from American Type Culture Collection (ATCC, Manassas, VA, USA).Cell lines were maintained in a humidified incubator with $5 \% \mathrm{CO}_{2}$ at $37^{\circ} \mathrm{C}$ and grown in Dulbecco's Modified Eagle's Medium (DMEM) (UFC biotech, Riyadh, KSA) for MCF-7 and BHK and in RPMI 1640 (UFC biotech, Riyadh, KSA) for Jurkat cells. All media were supplemented with $10 \%$ Fetal Bovine Serum (FBS) (Gibco U.S.A) and with $1 \%$ penicillin-streptomycin antibiotics (100 units/ml) (Gibco U.S.A). A $100 \mathrm{mM}$ solution of studied compounds was prepared in $100 \%$ DMSO (Dimethyl sulfoxide, Gibco U.S.A) or water. From the stock solution, appropriate working concentrations were prepared in the culture media where the final concentration of DMSO was less than $0.1 \%$ in both untreated and treated cells.

\section{Cell viability assay}

The cell proliferation assay test is a colorimetric assay that is based on the break of a tetrazolium salt (WST-1) by dehydrogenase in mitochondria to form formazan in viable cells. The higher the number of viable cells, the higher formazan produced following the addition of WST-1. It can be used also for detecting cytotoxicity.

Density of $10^{4}$ cells/well for HeLa, HepG2 and BHK cells were maintained and seeded on 96 multiwell plates. The cells were grown till the exponential phase and exposed to different concentrations of prepared microencapsulated $(10,20$ and 40 $\mu \mathrm{M})$ for several time periods $(24,48$ and $72 \mathrm{~h})$. Cell proliferation rate was evaluated through a rapid colorimetric cell proliferation assay using WST-1 reagent (Sigma Aldrich, USA). After incubation for the above mentioned duration, 10 $\mu \mathrm{L}$ of WST-1 solution was added and incubated for an additional $1 \mathrm{~h}$ at $37^{\circ} \mathrm{C}$. Finally, the absorbance was read at 450 $\mathrm{nm}$ with $\mathrm{ELx} 800^{\mathrm{TM}}$ micro plate ELISA reader (Biotek, USA) and the results were analysed by the Gen5 software (Biotek, USA). Thymoquinone was used as a positive control. The percentage of cell viability was calculated by assuming control (untreated) samples as $100 \%$ viable [14]. The $\mathrm{IC}_{50}(50 \%$ inhibitory concentration) values were calculated from the doseresponse curves.

\section{Apoptosis assay}

HeLa and HepG2 cells were plated in a 96-well plate at a density of $4 \times 10^{4}$ cells/well and incubated for $24 \mathrm{~h}$. After treating the cells with desired concentration of the drugs for several time periods, Annexin V/7AAD (Millipore ${ }^{\circledR}$, Billerica, MA) staining was carried out as per the manufacturer's protocol. Briefly, $100 \mu \mathrm{L}$ of nexin reagent (Millipore $^{\circledR}$, Billerica, MA) staining solution (containing annexin $\mathrm{V}$ fluorescein and 7AAD) was added and incubated at room temperature for $20 \mathrm{~min}$ in dark surroundings. The forward and side scatter was recorded at 10,000 events and the subsequent percentage of the early and the late apoptotic cells was analysed using the Guava ${ }^{\circledR}$ easyCyte 12 HT Benchtop Flow Cytometer (Millipore ${ }^{\circledR}$, Billerica, MA) and the results plotted using the In $\mathrm{Cyte}^{\mathrm{TM}}$ software (Millipore $^{\circledR}$, Billerica, MA).

\section{Statistical analysis}

Results were expressed as mean \pm SE. Triplicates teats were done in the same experiment. Student's t-test was calculated for comparison between the pairs. One way Analysis of Variance (ANOVA) was performed using SPSS version 15.

\section{Results and Discussion}

\section{GC/MS analysis of MEC}

Figure $1 \mathrm{GC} / \mathrm{MS}$ analysis of MEC showed that, measure RI at 1373 and reference RI at 1342 . This signal is specific for 1,3 , 5-benzenetriol that referred to $\mathrm{C}_{6} \mathrm{H}_{6} \mathrm{O}_{3}$.

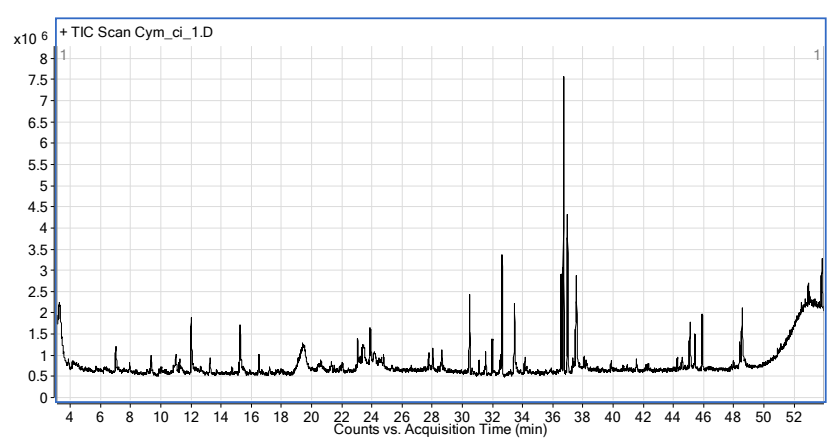

Figure 1. GC/MS analysis of MEC.

\section{Anti-proliferation activity of MEC}

Curcumin can exert its effect by initiating either intrinsic (mitochondrial) or extrinsic (receptor mediated) apoptotic pathways. The tumor suppressor p53 plays a pivotal role in initiating a caspase cascade through the immediate activation of pro-apoptotic proteins of B-cell lymphoma 2 (Bcl-2) family like Bcl-2 associated $\mathrm{X}$ protein (Bax) and $\mathrm{Bcl}-2$ homologous antagonist killer (Bak). These Bax and Bak perforate the mitochondrial membrane and hence release the cytochrome-c into the cytoplasm promoting mitochondria-mediated apoptosis. Curcumin also has the ability to inhibit antiapoptotic proteins like Bcl-2 and B-cell lymphoma extra-large (Bcl-xL) [15].

Molecular docking studies conducted by Luthra et al. confirmed the inhibition of $\mathrm{Bcl}-2$ by direct binding of curcumin to the second cavity of the protein through the intermolecular interactions of amino acids [16].

It was demonstrated that the curcumin inhibited the growth of colorectal carcinoma LoVo cells by initiating a caspase cascade at a considerable concentration of $0-30 \mu \mathrm{M}$. Moreover the nuclear staining by Annexin V/PI was found positive 
confirming the activation of apoptotic machinery. Recently, several reports have confirmed the anti-proliferative action of curcumin in cancers of breast, pancreas and lung through the down-regulation of Epidermal Growth Factor Receptor (EGFR) which is usually highly up-regulated in tumor environments [17].

The cell cycle is tightly regulated by a group of cell cycle regulatory proteins like cyclins and cyclin-dependant kinases (Cdk) which aid in the cell proliferation of the cells. But in tumors these regulatory proteins are up-regulated hence, leading to the rapid proliferation of cells. However, curcumin exerts its inhibitory effect on these regulatory proteins and inhibits the cell proliferation eventually [18].

Accumulating evidence shows that curcumin is not only antiproliferative or inhibits the reactive oxygen species but also found to promote apoptosis via induction of expression of different secondary messengers like nitric oxide synthase, COX-2, Matrix Metalloproteinase-2 (MMP-2) and Matrix Metalloproteinase-9 (MMP-9) in cancer cells. Sethi et al. have reported that abnormal inflammatory signaling pathways also play a pivotal role in the advancement and growth of several cancers [19].

The main objective of the research group is to serve the community by developing smart foods and diets that enhance quality of life and human health. In addition, build strong ties with organizations and institutions interested in these aspects. Main measures of the proposal will contribute to the overall objective by: capacity building, networking and twinning among research groups, research centres and institutions and linking to economic and social environment.

To determine the selectivity of MEC, the normal BHK cells were exposed to the similar concentrations of 1, 3, 5benzenetriol that was used with cancer cells for $24 \mathrm{~h}$. At a concentration of 10,20 and $40 \mu \mathrm{M}$, significantly caused cell proliferation inhibition of HeLa cells by about $91 \%$. However, increasing the concentration to $20 \mu \mathrm{M}$ induced a cell proliferation inhibition in HeLa and Hep2G by about $85 \%$ and $87 \%$ respectively. The cell viability at the highest concentration of $40 \mu \mathrm{M}$ was found to be $23.3 \%, 33 \%$, respectively for a time incubation of $24 \mathrm{~h}$ respectively.

Previous study found that inhibitory effect of on HepG2 and HeLa can be enhanced with the addition of curcumin. The mechanism curcumin may reduce the oxidation reaction. GC/MS analysis of MEC showed that, measure RI at 1373 and reference $\mathrm{RI}$ at 1342 . This signal is specific for 1, 3, 5benzenetriol that referred to $\mathrm{C}_{6} \mathrm{H}_{6} \mathrm{O}_{3}$.

Secondly, curcumin, itself has obvious effect of inhibiting tumor. Rezq et al. demonstrated that curcumin can make tumor cells sensitive, especially human colon carcinoma cells [12]. When different concentration of 1, 3, 5-benzenetriol were used, the inhibitory rate was decreased by $20.587 \%, 22.6 \%$ respectively. The synergistic anticancer effects fall decreased slowly with decreasing concentration of 1, 3, 5-benzenetriol. However, the inhibition rate of the mixture wills no longer increase that may be associated with low substrate concentration [20]. Hence, for the longer antitumor activity of the capsule it is advised to increase the concentration of 1, 3, 5benzenetriol in the treatment therapy (Table 1 and Figure 2).

Table 1. IC $C_{50}$ values $(\mu M)$ of the microcapsules against tumor cells and the normal cells are presented as mean \pm SE. Experiment was done triplicate ${ }^{a} p<0.05$.

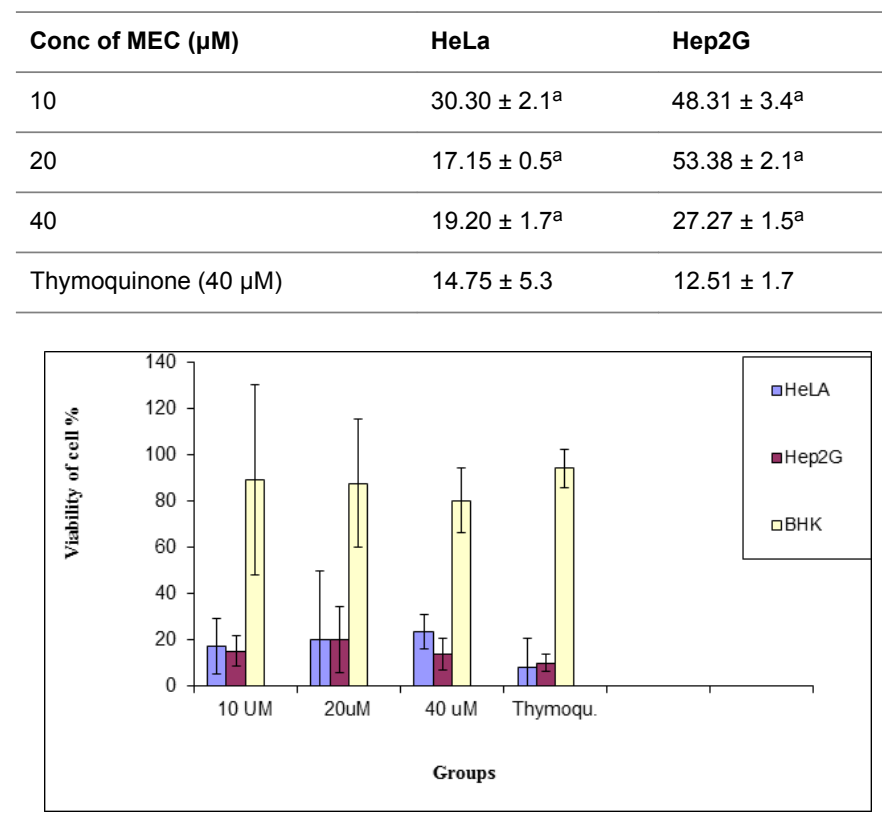

Figure 2. Antiproliferation activity of different concentrations of 1, 3, 5-benzenetriol.

\section{Detection of apoptosis}

Annexin V-7AAD staining of the HeLa cells which were treated with increasing concentrations $10,20,14 \mu \mathrm{M}$ for $24 \mathrm{~h}$ was detected. Increasing the concentrations 1, 3, 5-benzenetriol was associated with an increase in the number of apoptotic cells. It was found that, began to significantly trigger apoptosis at $10 \mu \mathrm{M}$. While at a concentration of $40 \mu \mathrm{M}$, the percentage of the annexin $\mathrm{V}$ positive cells was higher and approximately consistent with the value detected in cell viability assays. The present study involved the 1, 3, 5-benzenetriol of curcumin. The compounds showed potent effect on HeLa and Hep2 G cells with significantly higher anti-cancer activity. Taken together, curcumin-1, 3, 5-benzenetriol as promising in treatment of some cancer types.

\section{Acknowledgment}

This project was funded by the Deanship of Scientific Research (DSR) at King Abdulaziz University, Jeddah, under grant No. (G-410-247-38). The authors, therefore, acknowledge with thanks DSR for technical and financial support.

\section{References}

1. Baumgartl J, Baudler S, Scherner M, Babaev V, Makowski L, Suttles J, McDuffie M, Tobe K, Kadowaki T, Fazio S, Kahn CR, Hotamisligil GS, Krone W, Linton M, Brüning 
JC. Myeloid lineage cell-restricted insulin resistance protects apolipoproteinE-deficient mice against atherosclero-sis. Cell Metab 2006; 3: 247-256.

2. Galkina EV, Butcher M, Keller SR. Accelerated atherosclerosis in Apoe-/- mice heterozygous for the insulin receptor and the insulin receptor substrate-1. Arterioscler Thromb Vasc Biol 2012; 32: 247-256.

3. Moore KJ, Tabas I. Macrophages in the pathogenesis of atherosclerosis. Cell 2011; 145: 341-355.

4. Mazumder PK, O’Neill BT, Roberts MW, Buchanan J, Yun UJ, Cooksey RC, Boudina S, Abel ED. Impaired cardiac efficiency and increased fatty acid oxidation in insulinresistant ob/ob mouse hearts. Diabetes 2004; 53: 2366-2374.

5. Betuing S, Tuttle MJ, Graveleau C, Young ME, Pham M, Zhang D, Cooksey RC, McClain DA, Litwin SE, Taegtmeyer H, Severson D, Kahn CR, Abel ED. Insulin signaling coordinately regulates cardiac size, metabolism, and contractile protein isoform expression. J Clin Invest 2002; 109: 629-639.

6. Boudina S, Bugger H, Sena S. Contribution of impaired myocardial insulin signaling to mitochondrial dysfunction and oxidative stress in the heart. Circulation 2009; 119: 1272-1283.

7. Laustsen PG, Russell SJ, Cui L, Entingh-Pearsall A, Holzenberger M, Liao R, Kahn CR. Essential role of insulin and insulin-like growth factor 1 receptor signaling in cardiac development and function. Mol Cell Biol 2007; 27: 1649-1664.

8. Lofqvist C, Willett KL, Aspegren O, Smith AC, Aderman CM, Connor KM, Chen J, Hellstrom A, Smith LE. Quantification and localization of the IGF/insulin system expression in retinal blood vessels and neurons during oxygen-induced retinopathy in mice. Invest Ophthalmol Vis Sci 2009; 50: 1831-1837.

9. Rajala A, Tanito M, Le YZ, Kahn CR, Rajala RV. Loss of neuroprotective survival signal in mice lacking insulin receptor gene in rod photoreceptor cells. J Biol Chem 2008; 283: 19781-19792.

10. Jiang ZY, He Z, King BL, Kuroki T, Opland DM, Suzuma K, Suzuma I, Ueki K, Kulkarni RN, Kahn CR, King GL. Characterization of mul-tiple signaling pathways of insulin in the regulation of vascular endothelial growth factor expression in vascular cells and angiogenesis. J Biol Chem 2003; 278: 31964-31971.

11. Welsh GI, Hale LJ, Eremina V. Insulin signaling to the glomerular podocyte is critical for normal kidney function. Cell Metab 2010; 12: 329-340.
12. Mima A, Ohshiro Y, Kitada M, Matsumoto M, Geraldes P, Li C, Li Q, White GS, Cahill C, Rask-Madsen C, King GL. Glomerular-specific protein kinase $\mathrm{C}$ - $\beta$-induced insulin receptor substrate-1 dysfunction and insulin resistance in rat models of diabetes and obesity. Kidney Int 2011; 79: 883-896.

13. Rask-Madsen C, King GL. Mechanisms of Disease: endothelial dysfunction in insulin resistance and diabetes. Nat Clin Pract Endocrinol Metab 2007; 3: 46-56.

14. Brown MD, Hart C, Gazi E, Gardner P, Lockyer N. Influence of omega-6 PUFA arachidonic acid and bone marrow adipocytes on metastatic spread from prostate cancer. Br J Cancer 2010; 102: 403-413.

15. Tajbakhsh S, Mohammadi K, Deilami I, Zandi K, Fouladvand M, Ramedani E. Antibacterial activity of indium curcumin and indium diacetylcurcumin. African $\mathrm{J}$ Biotechnol Acad J (Kenya) 2008; 7: 3832-3835.

16. Luthra PM, Kumar R, Prakash A. Demethoxycurcumin induces Bcl-2 mediated G2/M arrest and apoptosis in human glioma U87 cells. Biochem Biophys Res Commun 2009; 384:420-425.

17. Chowdhury $\mathrm{H}$, Banerjee $\mathrm{T}$, Walia $\mathrm{S}$. In vitro screening of Curcuma longa L. and its derivatives as antifungal agents against Helminthosporium oryzae and Fusarium solani. Pestic Res J Soc Pest Sci India 2008; 20: 6-9.

18. Odds FC. Synergy, antagonism, and what the chequerboard puts between them. J Antimicrob Chemother 2003; 52: 1.

19. Kim M, Choi G, Lee HS. Fungicidal property of Curcuma longa L. rhizome-derived curcumin against phytopathogenic fungi in a greenhouse. J Agric Food Chem 2003; 51: 1578-1581.

20. Haast RA, Kiliaan AJ. Impact of fatty acids on brain circulation, structure and function. Prostaglandins Leukot Essent Fatty Acids 2015; 92: 3-14.

\section{*Correspondence to}

Jehan A. Khan

Department of Biology (Genomic Division)

Faculty of Science

King Abdulaziz University

Kingdom of Saudi Arabia 